Juliusz Pietrzak

INSEEC Busines School

e-mail: julekpietrzak@gmail.com

\title{
The issue of managing technical project teams within European Companies ${ }^{1}$ Zagadnienie relacji pracowników z kierownikiem projektu w przedsiębiorstwach europejskich
}

https://doi.org/10.25312/2391-5145.15/2020_06jp

\begin{abstract}
The article deals with the problem of the relationship between an employee and a project manager. The research aims to examine the employee - project manager relationship in the projects of European companies. The article consists of two main parts. The first is theoretical, the second empirical. The empirical data was collected by conducting semi-structured interviews with five project managers and five team employees.
\end{abstract}

Keywords: project management, relationship, manager, employee.

\section{Streszczenie}

Artykuł podejmuje problematykę relacji między pracownikiem a kierownikiem projektu. Badania mają na celu rozpoznanie relacji między pracownikiem a kierownikiem projektu w ramach projektów realizowanych w przedsiębiorstwach europejskich. Struktura artykułu składa się z dwóch głównych części. Pierwsza z nich jest teoretyczna, druga empiryczna.

\footnotetext{
1 Part of dissertation The IT project team management of the example of the xyz companies written under the supervision of dr inż. Agnieszka Pietras and Ph. D Stephanie Prat.
} 
Dane empiryczne zostały zebrane za pośrednictwem niestandaryzowanych wywiadów z pięcioma kierownikami projektów i pięcioma pracownikami zespołu.

Słowa kluczowe: zarządzanie projektem, relacje, kierownik, pracownik

In our everyday life, we meet with different projects. Several of the oldest mentions of projects concern the Pyramids or the Great Wall of China. In order to create a product or service, we need a pre-prepared design that will allow us to organise our work quickly and efficiently. In the beginning, projects were mainly related to the creation of new buildings or products. Nowadays, projects are also needed to create services that are willingly used by consumers. In the business sector, the notion of a project is relatively new. The change in the structure of the company and the increase in the flow of information means increased demand for creating a new form - the project. We can collect and process relevant information needed to work, search and define procedures to facilitate the achievement of the goal and create the necessary teamwork to achieve the success of others. Projects are collections of various tasks performed to achieve a set of goals and a measurable, long-lasting result. One of the most known definition of the project is formulated by the Project Management Institute, which defines a project as a "temporary endeavour aimed at creating a unique product or service where temporariness means that the endeavour has a strictly defined beginning and end, and uniqueness means that the product or service is significantly different from any other similar products or services."2. Furthermore, one of the essential parts of managing projects as a whole is team management. Especially in a highly technical environment, people are often stuck while managing complex projects. What is more, the project manager may have to manage people with more technical knowledge than he already has. Such a situation may be an obstacle for leading the team at the beginning, but it can be successfully resolved in the future.

\section{Relationship between team employee and project manager}

The relationship between the manager and the employee can differ significantly. Additionally, employees often misinterpret the relationship with their managers. The misinterpretation of this relationship can lead to an uncooperative and unhealthy work environment. Employee's success and career progression depend on how vital the relationship with his manager is ${ }^{3}$. One of the most essential thing is to create a synergistic work environment by maintaining a healthy relationship between manager and employee. Employees in the high technology sector are people with knowledge who are engaged

\footnotetext{
${ }^{2}$ Guide to the Project Management Body of Knowledge (PMBOK® Guide) - Sixth Edition, Project Management Institute, Newton Square 2017.

${ }^{3}$ H. Brittany, How Is Your Relationship with Your Boss, Do You Know?, "Black Enterprise”, 2012, p. $55-56$.
} 
in finishing their task. Managers has a direct and constructive impact on others ${ }^{4}$ They often adopt the activities and behaviours of the employees to stimulate and accelerate task accomplishment. An Project Manager has to use several types of communication to be successful in project management. Communication is not only about producing status reports and management presentations but is also about getting the relevant information to the appropriate people in the desired time. The Project Manager has to communicate the project vision, strategy, priorities and plan to other team members to maintain their focus on the overall development and goals. Team members want to understand the daily activities and know how the work they are performing is moving forward ${ }^{5}$. Unfortunately, communication between managers and employees is not always clear. This disconnect between them could be the results of misperceptions or unclear results of both parties ${ }^{6}$. In the other hand, sometimes it can happen that, the problem is not an unclear communication but total lack of communication. In this case, the solution should be an project team training engaging communication within them ${ }^{7}$. Successful managers can improve communication channels and manage a stakeholder effectively. Their communication skills should be at an excellent level.

\section{Barriers and conflict management within teams}

Communication process requires two parties. The first part is a sender, who send encoded message, and the second one is the receiver who decodes the message. This model does not include the need to ensure that the message has been understood. The barriers might deteriorate the understanding of the message. Receiver can be distracted, perceive message in another way or have lack of knowledge required to follow up the project ${ }^{8}$. Other main barriers, which can worse relationship in Project Management are: working simultaneously on several levels and projects, a lack of knowledge and very tight project deadlines ${ }^{9}$. Overcoming all barriers is not always feasible, but it is worth to minimise their impact on project management in order to achieve a successful business relationship with the project team. Conflict arises as a result of group problem-solving operations. In projects, where more than one people need to make decisions, there may happen a disagreements. Therefore, conflict management skills are necessary to solve the problems of teams ${ }^{10}$. In other hand, conflicts can be beneficial to employees, because involved people can acquire more information, share their thoughts and ideas, and make high-quality

\footnotetext{
${ }^{4}$ A.P. Harold, Expression of Dissatisfaction in Relation to Managerial Leadership Strategies and Its Impact in Information Technology Organizations, "Skyline Business Journal" 2012, p. 29-35.

${ }^{5}$ K.R. Wills, Applying guiding principles of effective program delivery, CRC Press, 2016, p. 181-183.

${ }^{6}$ H. Brittany, op. cit., p. 55-56.

7 J. Moustafaev, Project Scope Management: A Practical Guide to Requirements for Engineering, Product, Construction, IT and Enterprise Projects, CRC Press, Boca Raton 2014.

${ }^{8}$ Guide to the Project Management Body of Knowledge..., op. cit.

${ }_{9}$ M. Alexandre, T. Fernando de Souza, M. Heverton, R. Oliveira, C. Moraes, Barriers to the use of an IT Project Management Methodology in a large financial institution, "International Journal of Project Management" 2016, 34(3), p. 467-479.

${ }^{10}$ E. Verzuh, The fast forward MBA in project management, 5th ed., 2015.
} 
decisions. Managers should maintain a certain level of conflicts management to achieve peak employee agility ${ }^{11}$. Not every employee can manage conflicts successfully, but every employee is able to train and improve this skill over time. Conflict management is not a critical skill just only for project leaders but also for a whole team. This skill enables team members to create better ideas and correctly maintain better team relationship ${ }^{12}$.

\section{Motivational aspects of cultural differentiated managing team}

Motivation is one of the essential components influencing team project management. Especially in the technical environment, motivation plays a massive role. Many of senior specialist try to work alone and often lose motivation in pursuing team goals. Without motivation, every other aspect of project management can easily fall. Additionally, employees surely need to be motivated to maintain better performance. The leading role of team motivating is the role of the project manager, who conduct different task to motivate employees. In order to understand the meaning of the motivation process, one should start by explaining the term "motivation". The origins of this word can be traced back to Latin, as the word "movere" directly means "to move" and "to stimulate something". Motivation is natural to the process of energy transfer. In turn, the concept of motivation comes from the field of psychology. Motivation creates a desire to act. Other sources define the motivational slogan as a mechanism of a psychological nature, which is responsible for initiating, acting on the goal that an individual wants to achieve. According to S. P. Robbins, motivation is determined by the circumstances in which the needs can be met. Motivation is one of the factors that shape our actions. To manage teams, there are several skills required in order. One of the essential project manager skills are strong communicative and interpersonal skills ${ }^{13}$. He also has to be familiar with the operations and technology used into projects. Technical skills are more available to learn then ease of work with people. Therefore, the project manager should be ready to manage relationship within the team and between team and outer entitles (i.e. senior management, customer). Although interpersonal skills are crucial, technical skills are also required to be effective.

\section{Conclusion}

The relationship between the employee and the project manager has the greatest influence on the process of project management. In order to achieve the best possible results, we strive to strengthen communication between the employee and the project manager. It is also very important to have a close relationship based on trustworthy atmosphere, which increases cooperation and confidence. Many of the respondents also indicate

11 A.H. Pitafi, H. Liu, Z. Cai, Investigating the relationship between workplace conflict and employee agility: The role of enterprise social media, "Telematics and Informatics" 2018, p. 2157-2172.

12 E. Verzuh, op. cit.

${ }_{13}$ H. Kerzner, Project Management: A Systems Approach to Planning, Scheduling, and Controlling, John Wiley \& Sons, Hoboken 2013. 
integrative out-of-work activities, which embody the relationship between co-workers. Education is also a very important component that affects project management. After the analysis of the research, it is clear that the managerial positions are held by persons who have completed higher education studies. The general knowledge gained during the studies is considered to be the knowledge that is necessary for efficient project management, but nevertheless it often lacks the practical aspect, which is acquired while working in a project team. A noticeable component that affects project management is also the motivational role of the project manager. The study participants revealed additional motivation caused by the role of the project manager. For some people, it is also a dream career position, which pushes them towards further learning. Even if someone is not a project manager, they are willing to take up the learning challenge as much as possible in order to increase their vocational competences and become more prepared for upcoming project challenges. Many participants also indicated the correlation between employee effectiveness and project success. The cooperation of employees contributes to the increase of effectiveness and, consequently, greater motivation to achieve success. Employee effectiveness also reduces the risk of error, which has a positive impact on project quality. Our goal is to maximise profits and, consequently, high efficiency of teams. All this has an impact on the effectiveness of the project, project success and project management. In order to improve own results it is sometimes good to improve the quality of communi-

cation between teams. It is also important to be well prepared for the project by estimating the duration of individual tasks, risks and project changes that directly affect the project.

\section{Bibliography}

Alexandre M., Fernando de Souza T., Heverton M., Oliveira R., Moraes C., Barriers to the use of an IT Project Management Methodology in a large financial institution, "International Journal of Project Management" 2016, 34(3).

Brittany H., How Is Your Relationship with Your Boss, Do You Know?, "Black Enterprise" 2012, 42(11).

Guide to the Project Management Body of Knowledge (PMBOK® Guide) - Sixth Edition, Project Management Institute, Newton Square 2017.

Harold A.P., Expression of Dissatisfaction in Relation to Managerial Leadership Strategies and Its Impact in Information Technology Organizations, "Skyline Business Journal” 2012, 8(1).

Kerzner H., Project Management: A Systems Approach to Planning, Scheduling, and Controlling, John Wiley \& Sons, Hoboken 2013.

Moustafaev J., Project Scope Management: A Practical Guide to Requirements for Engineering, Product, Construction, IT and Enterprise Projects, CRC Press, Boca Raton 2014.

Pitafi A.H., Liu H., Cai Z, Investigating the relationship between workplace conflict and employee agility: The role of enterprise social media, "Telematics and Informatics" 2018, 35(8).

Verzuh E., The fast forward MBA in project management, $5^{\text {th }}$ ed., 2015.

Wills K.R., Applying guiding principles of effective program delivery, CRC Press, 2016. 